\title{
2. 植物ホルモンと矮性
}

\section{山根久和 東京大学農学部}

矮性が農業上有用な形質として利用されている例は少 なくない、メキシコやインドで飛䧸的な增収をもたら し，いわゆる緑の革命 (green revolution) の主役となっ たメキシュコムギななら゙にフィリピンの国際イネ研究 所 (IRRI) で開発され，約 2 倍の収量をもたらしたミラ クルライス (IR-8) は短桿性品種である. ダイズやアズ キも野生型は蔓性であることから，現在の栽培種は矮性 種といらこともできる。また，果樹栽培に抢いても矮性 化は作業の効率化を図る上できわめて重要である.

矮性は伸長成長似関する突然変異の中でも代表的なも ので，正常な生長を調節する過程の一部に起こった異常 とよるものと考光られる。すなわち，成長ホルモンの生 合成，その受容，それに続く受容シグナル伝達機構，さ らには細胞分裂，細胞壁構築などの伸長成長現象発現に いたるいずれかの過程に異常があると考えられる。した がって, 矮性植物に晾沙る矮化機構の研究は，正常な伸 長成長の素過程を明らかにする研究に添かならないとも いえる.

本稿では, 植物ホルモンに関連した最近の矮性研究に ついて解説するが，他にも本稿に関連した総説(1 4)があ るので併せて参照していただけれ㓑いである。

\section{ジベレリンと矮性}

1. 活性型ジベレリン

ジベレリンは, もともと植物病原菌 Gibberella fujikuroi によってひき起こされるイネ馬鹿苗病の病徴誘起 物質として単離構造決定されたものであるが, 植物ホル モンとして, 種々の重要な生理的役割を果たしている(5). ジベレリンが示す多椂な生理作用のうら，最も顕著なむ のは節間伸長促進作用であることから，古くから矮性と の関連が広範に研究されてきた。

現在、ジベレリンは高等植物から 70 種以上が単離・

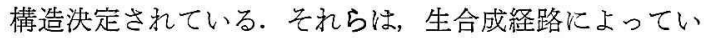
くつかのグループに分類され，それぞれの生合成経路 は，末端において活性型ジべレリンを生成すると考えら れる．現在まで高等植物に括いて機能していることが明: らかにされた生合成経路は，生合成の早い時期に C-13. 位（図 1) に水酸基が導入される early-13-hydroxylation. pathway（図 2）と，生合成後期侄るまでジベレリン の母核に水酸基が 導入されない early-non-hydroxylation pathway である(6).

前者に新ける活性型ジベレリンは, $\mathrm{GA}_{20}$ の $\mathrm{C}-3 \beta$ 位 の水酸化により生成する $\mathrm{GA}_{1}$ で, トウモロニシ（Zea mays L. $)^{(7)}$, イネ (Oryza sativa L. $)^{(6)}$, エンドウ (Pisum sativum L.) $)^{(8 \sim 10)}$ をはじめとする多数の植物の茎葉. の伸長成長の制御に与っている. $\mathrm{GA}_{20}$ からの分岐経路 により $\mathrm{GA}_{5}$ を経て生成する $\mathrm{GA}_{3}{ }^{(11,12)}$ も $\mathrm{GA}_{1}$ と同程 度の活性をるつ活性型ジベレリンであり，トウモロ二 シ(13)，アブラナ科植物である Brassica rapa $a^{(14)}$ や B. napus ${ }^{(15)}$ ，サトウキビ (Saccharum spp. hybrid)(16) な. ぞの茎部に存在する.しかし, 先の場合 $\mathrm{GA}_{1}$ が共存し ており, 茎葉において $\mathrm{GA}_{3}$ が主要活性型ジベレリンと して認められた例はきわめて少なく，また $\mathrm{GA}_{3}$ の果た 寸生理的役割についても現在のところ明らかでない。

一方，後者においては $\mathrm{GA}_{9}$ が $3 \beta$ 水酸化されて生成 する $\mathrm{GA}_{4}$ が活性型ジベレリンで，キュウリの茎葉の

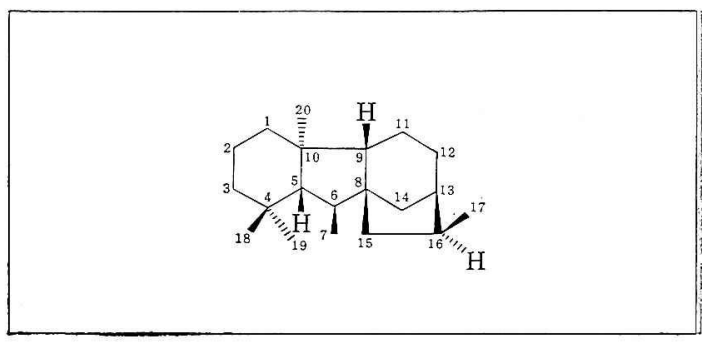

図 1 ロジベレリンの基本骨格の炭素番号 


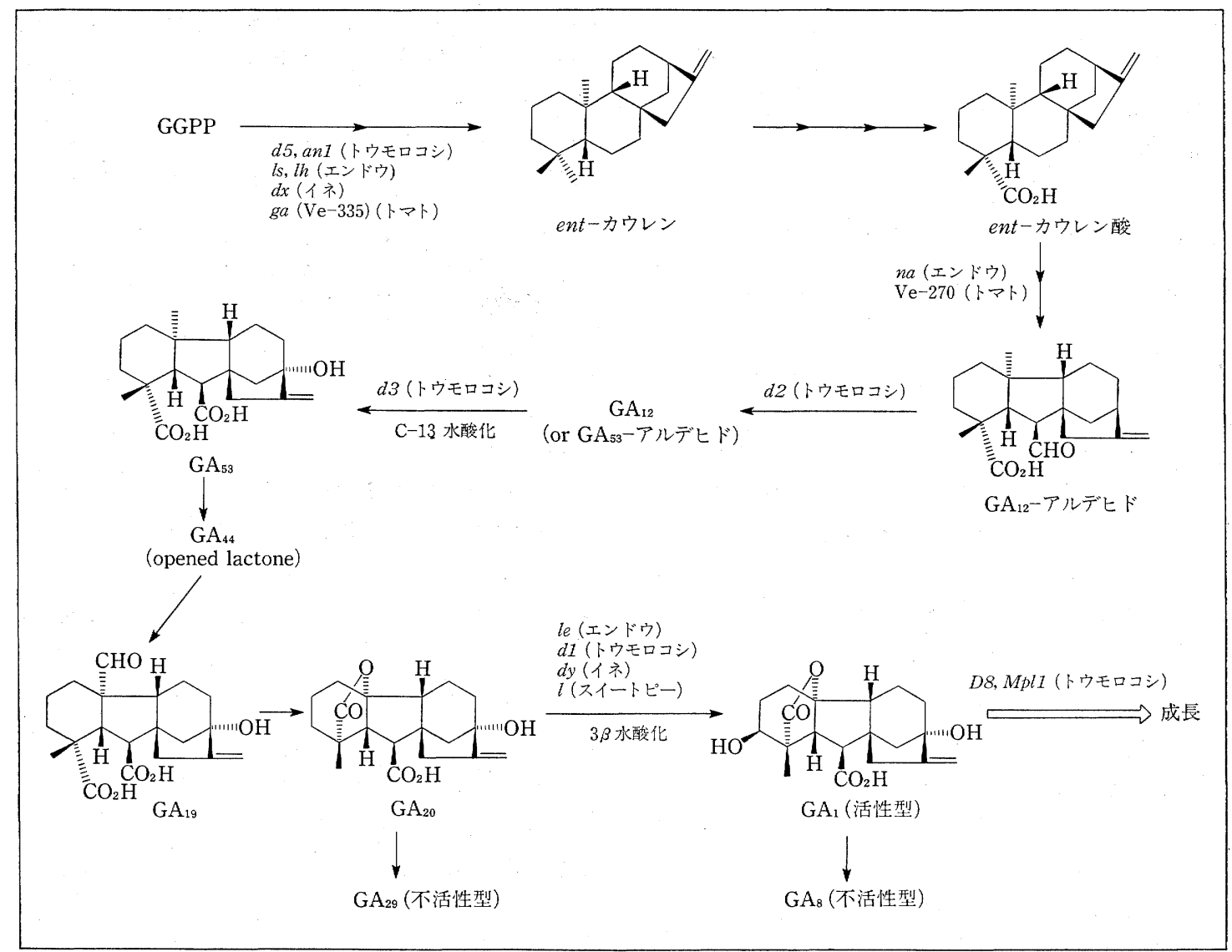

図 2 ・トウモロコシ,イネ, エンドウ,トマト,スイートピー葉条において想定されるジベレリンの生合成経路（early13-hydroxylation pathway) ならびに矮化遺伝子によってブロックされている段階 $(3,18,26)$

GGPP : ゲラニルゲラニルピロリン酸

伸長を制御している(17). この経路において $\mathrm{GA}_{9}$ からの 分岐経路で 2,3-didehydro-GA9 を経て生成する $\mathrm{GA}_{7}{ }^{(12)}$ も活性型と考えられるが, 茥葉部から $\mathrm{GA}_{7}$ が主要活性 型ジベンリンとして同定された例はない.

活性型ジベレリンという概念は新しいものではない

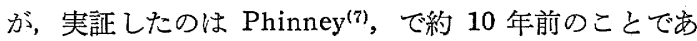
る. 彼はジベンリン生合成経路上に遺伝的欠陥を有する 4 種の単一遺伝子突然変異 (single-gene mutants), $d 1$, $d 2, d 3$ および $d 5$ を駆使した研究に基づいて，「トウ モロコシの茎部に和いて，そのままの形で活性を示すジ ベレリンは生合成経路末端の $\mathrm{GA}_{1}$ であり，内生ジベレ リンのうち生物検定で活性なものは生体内で $\mathrm{GA}_{1}$ に変 換されて活性を示す」という説を提出した. すでに述 ベたようにキュウリにおいては活性型ジベレリンは $\mathrm{GA}_{4}$ であるが，トウモロコシに拈ける $\mathrm{GA}_{20}$ から $\mathrm{GA}_{1}$
と,キュウリにおける $\mathrm{GA}_{9}$ から $\mathrm{GA}_{4}$ への変換段階は C-13 水酸基の有無で対応して和り， $3 \beta$ 水酸化が活性型 ジベレリンを生成する最終段階であるという点で Phinney の説は普遍性を有するものといえよう.こうして, 活性型ジベレリンという概念の 普遍性が実証されたこ と、また GC/MS 法をはじめとする機器分析の発達によ り正確な内生量の測定, 代謝実験に和ける微量代謝物の 同定が可能になったことなどにより，矮性の生理生化学 的解析は大きく進展しつつある.

\section{2. ジベレリン生合成の異常と矮性}

ジベレリン関連矮性突然変異の要因は, 生合成経路上 に異常を有するために活性型ジベレリンが正常成長に必 要な量生産されない場合, 活性型ジベレリンは必要量生 成されるがその受容あるいは受容シグナル伝達機構に異 
常がある場合に大別される.

トウモロコシの $d 1, d 2, d 3, d$ 5 は, 各種ジベレリンを用いた生物 検定，放射性同位元素標識化合物を 用いた代謝実験により，それぞれ図 2 亿示した生合成段階に欠陥がある と推定されてきたが，このことは内 部標準を用いた GC/SIM 法による 内生ジベレリンの定量によっても支 持された (表 1) ${ }^{(18)}$. これらの突然变 異は $\mathrm{GA}_{1}$ が不足しているため矮性となっているわけで， 活性型であるGA 正常型之同等な成長を示す. また, $d 1, d 2, d 3, d 5$

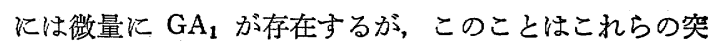
然変異がいわゆる leaky mutants（漏出性突然変異体） で，完全な GA 生合成阻害をもたらするのではないこと を意味している. $d 1$ と $d 5,2$ つの矮性遺伝子を有す る double mutant は $\mathrm{GA}_{1}$ の内生レベルが一層低下し， 矮化がさらに著しいものとなる，その他，トゥモロコシ に怙いては，ent-カウレン生成段階に 異常を有する $a n$ $I^{(19)}$ も存在する.

トランスポゾンを導入して得られる矮性植物のうち, 外生的に与えたジベレリンに反応して正常回復するもの は, トランスポゾンが導入されたためにジベレリン生合 成酵素の遺伝子発現が何らかの影響を受けた可能性が考 兄らる. Phinney ら ${ }^{(20)}$ は, Robertson によって作出さ れたトウモロコシのジベレリン感受性トランスポゾン導 入矮性を用い, トランスポゾンとハイブリダイズする DNA をプローブとして，矮化遺伝子のクローニングを 試みたが，実際には多数のコピーが導入されて括り成功 には至らなかった。

イネに拉ける矮性 $d y$ (矮稲 C) は, ジベレリンの活性 化段階である $3 \beta$ 水酸化段階洪常を有することが生物 検定により推定され视，さらに内生ジベレッンの分析に より確認された(6). イネ $d x$ (短銀坊主) に和いては, ent-カウレン生成段階に 異常があることが生物検定に 基づいて推定されている(6)が，ent-カウレンの内生量に $d y$ や正常型のイネと特筆すべき差はなかった (22). 今後,

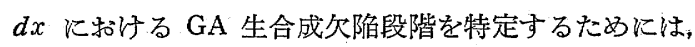
$d x$ とその isogenic line である正常型との間で, entカウレンの内生量, 生合成・代謝能などの比較を行なら
必要がある.

エンドウの $l s, l h$ は, ent-カウレン生成段階に, $n a$ は $\mathrm{GA}_{12}$-アルデヒド生成段階に, $l e$ は $\mathrm{GA}_{1}$ 生成段階にそれ ぞれ欠陥を有する矮性であることが明らかにされてい る(23)、トウモロコシの場合と同様, これらの変異体は leaky mutants であり，矮性がより顕著な $l e^{d}$ や double mutant の na ls も報告されている(23).

植物分子生物学の研究材料として好適なことから, 近年注目を集めているシロイヌナズナ（Arabidopsis thaliana L。) 飞执いても, ジベンリン生合成経路に異常 を有すると考㝋られている, ga 1, ga 2, ga 3, ga 4, ga 5 の 5 種の矮性突然変異が存在する. これらのうち， $g a$ 1, ga 2, ga 3 はジベレリン処理することによりはじめ て発芽生育する. 最近, Talon ら ${ }^{(24)}$ は, 野生型のシロイ ヌナズナから GC/MS により内生ジベレリンとして, $\mathrm{GA}_{1}, \mathrm{GA}_{4}, \mathrm{GA}_{8}, \mathrm{GA}_{12}, \mathrm{GA}_{13}, \mathrm{GA}_{15}, \mathrm{GA}_{17}, \mathrm{GA}_{19}$, $\mathrm{GA}_{20}, \mathrm{GA}_{24}, \mathrm{GA}_{25}, \mathrm{GA}_{27}, \mathrm{GA}_{29}, \mathrm{GA}_{34}, \mathrm{GA}_{36}, \mathrm{GA}_{37}$, $\mathrm{GA}_{44}, \mathrm{GA}_{51}, \mathrm{GA}_{53}$ を同定し,さらに上記のジベレリン

表 2 シロイヌナズナの野生型, ga4,ga5 における内 生ジベレリンの内部標準を用いた GC/SIM 法による定 量(24)

\begin{tabular}{|c|c|c|c|}
\hline \multirow{2}{*}{$\begin{array}{l}\text { ジベレリン } \\
(\mathrm{GA})\end{array}$} & \multicolumn{3}{|c|}{ 内生量 (ng/100g 新鮮重) } \\
\hline & 野生型 & $g a 4$ & $g a 5$ \\
\hline \multicolumn{4}{|l|}{$\mathrm{C}_{20}-\mathrm{GA}_{5}$} \\
\hline $\mathrm{GA}_{53}$ & 701 & 318 & 2215 \\
\hline $\mathrm{GA}_{19}$ & 1174 & 2675 & 1081 \\
\hline \multicolumn{4}{|l|}{$\mathrm{C}_{19}-\mathrm{GA}_{5}$} \\
\hline $\mathrm{GA}_{1}$ & 34 & 12 & 10 \\
\hline $\mathrm{GA}_{4}$ & 539 & 149 & 52 \\
\hline $\mathrm{GA}_{8}$ & 1148 & 430 & 243 \\
\hline $\mathrm{GA}_{9}$ & 310 & 995 & 23 \\
\hline $\mathrm{GA}_{20}$ & 29 & 285 & 6 \\
\hline
\end{tabular}

分析試料：短日条件下で播種後 $40 \sim 45$ 日間育て, 花芽が現わ れた時点で長日条件に移し，さらに 4 日間生育させた植物. 
のらち 7 種について, 内部標準を用 いた GC/SIM 法によって, ga 4, ga 5 と野生型で内生量の比較を行な った（表 2). その結果, ga 4 におい ては $3 \beta$ 水酸基を有するジベレリン の内生量が少なく, $3 \beta$ 水酸化段階 に異常があると推定された. ga 5 で は, $\mathrm{C}_{19}$ ジベレリン内生量が少ない

一方で, $\mathrm{GA}_{53}, \mathrm{GA}_{19}$ などの $\mathrm{C}_{20}$ ジベレリン内生レベル

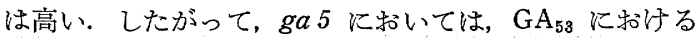
$\mathrm{C}-20$ の水酸化と $\mathrm{GA}_{19}$ に怙ける $\mathrm{C}-20$ の脱離が同じ酵 素で触媒されているとすればとの酵素に，むし別々の酵 素で触媒されているとすれば両酵素の共通の因子に変異 が起こっていると考えられる.

その他，トマト (Lycopersicon esculentum Mill.) の $g a(\mathrm{Ve}-335$; ジベレリン処理によって発芽生育する)は ent-カウレン生成段階に, Ve-270 は $\mathrm{GA}_{12}$-アルデヒド 生成段階に ${ }^{(25)}$ ，スイートピー (Lathyrus odoratus L.) の $l$ は $\mathrm{GA}_{1}$ 生成段階に異常がある(23) と報告されてい る. Brassica rapa の矮性 rosette の菱葉に执いては, 活 性型ジベレリンである $\mathrm{GA}_{1 / 3}$ の内生レベルは対応する 正常型より低いが，年の原因は明らかにされていな $\omega^{(14)}$.

\section{3. ジベレリンに対する反応性の異常と矮性}

外生的に与皃たジベレリンに反応しない，あるいは低 反応性のジベレリン関連の矮性は, ジベレリンの受容, あるいは受容シグナル伝達機構に和ける異常に起因する 可能性が考えられる. トウモロコシの $D 8, M p l 1$ は, ジベレリンに反応しない優性の矮性であり，遺伝子の機 能解析の結果から，ジベレリン受容体の異常であること が示唆された(26). Mpl 1 $D 8$ より軽度の矮性で, 植 物の背丈は $+/+>M p l 1 /+>+/ D 8>D 8 / D 8$ で ある. $D 8$ の内生ジベレリンに関しては詳細な分析結果 が報告されている(13). 活性型ジベレリンである $\mathrm{GA}_{1}$.の 内生量は, $+/+: D 8 /+: D 8 / D 8=1: 33: 60$ で背丈 と逆の関係になっている. 他のジベレリン生合成中間体 の内生レベルも同様の傾向を示した（表 3）(13). 受容体 異常の变異体に括いては, 過剩の $\mathrm{GA}_{1}$ の存在も植物に とって害はなくジベレリン生合成のフィードバック阻害 の要因とはならないことから、ジベレリンが過剰生産さ
れるのかもしれない. コムギ (Triticum aestivum L.) の Rht $1^{(27)}, R h t 2^{(27)}, \quad R h t 3^{(28)}$, シロイヌナズナの $g a i^{(29)}$ b, 対応する正常型植物より多量の GA を生産す ることが示されており，これらも受容体異常の可能性が ある.

インゲンマメ (Phaseolus vulgaris L.) には, 蔓性のも のと䒤なしのものがある. Endo ら ${ }^{(30)}$ は, 蔓性のケンタ ッキーワンダー, 瞢なしのマスターピース, マントルに ついて内生ジベレリンレベル，外生的に与えたジベレリ ンに対する反応性を比較した. マスターピース，マント ルは，比較的多量のジベレリンで処理すると瞢を生じ， ケンタッキーワンダーと同様の形状を示す品種である. 内生ジベレリンに関しては，質的にも量的にも 3 種の間 に特筆すべき差はなかったが，外生的に与えた $\mathrm{GA}_{1}$ に 対する反応性については大きな差があり，蔓なしの 2 種 は蔓性のケンタッキーワンダーの約 1/100 の反応を示し たにすぎなかった。、マスターピース，マントルの矮性 は, ジベレリンの受容, あるいは受容シグナル伝達機構 における異常に起因する可能性が考光られる.

\section{オーキシンと矮性}

高等植物に和いては, インドールー3-酢酸 (IAA) の生 合成経路は長い間判然としなかったが，最近 Lートリプ トファンから D-トリプトファン, インドールピルビン 酸，インドールアセトアルデヒドを経る経路（図 3）が 主要なものである可能性が示された ${ }^{(31)}$. Lートリプトフ アンから直接インドールピルビン酸を生成する L-トリ プトファンアミノトランスフェラーゼも植物組織に存在 するが, 至適温度は $50 \sim 60^{\circ} \mathrm{C}$ であり, 実際に IAA の 生合成に拈いて機能しているとは考えにくい. 一方, D-トリプトファンアミノトランスフェラーゼの至適温 度は $30^{\circ} \mathrm{C}$ 付近である(32). また，オオムギ（Hordeum vulgare L.) 幼葉鞘に対する $\mathrm{D}-$, L-トリプトファンの 


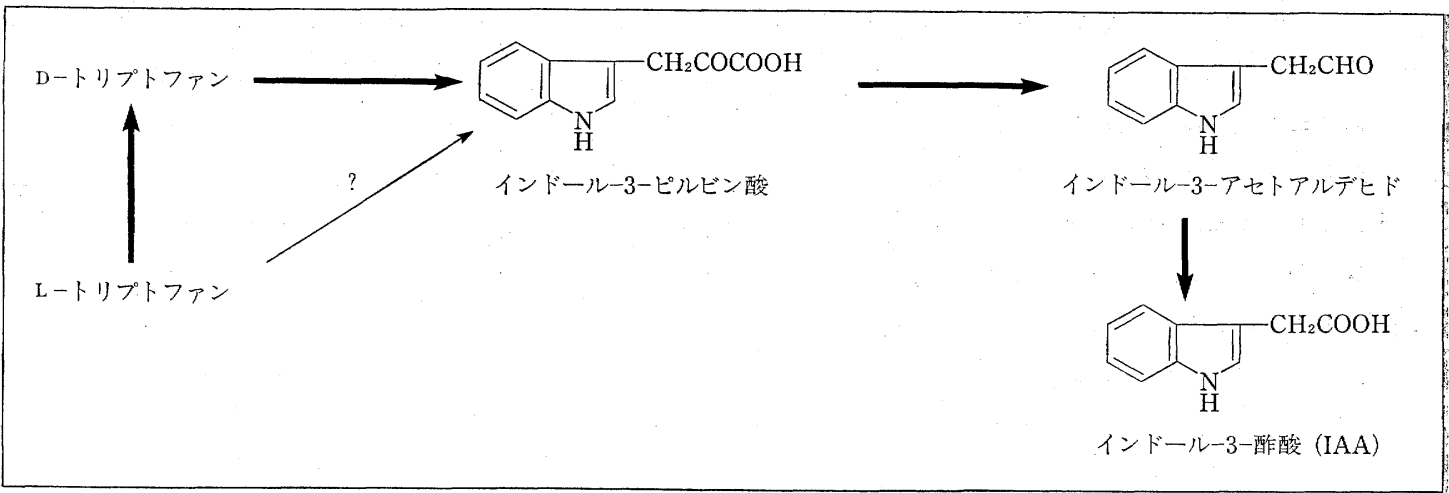

\section{図 3 高等植物において想定されるインドール-3-酢酸（IAA）の主要生合成経路}

伸長促進効果を検定したところ，L 型よりD型の汇うが 高い活性を示した.ささらに，Dーアミノ酸アミノトラン スフェラーゼの阻害剤である D-シクロセリンは D-ト リプトファンによる伸長促進効果を阻害したが IAA に よるそれは阻害しなかっだ(33). これらの事実は，IAA が Dートリプトファンを経て生合成される可能性を支持 するものである.

Inouhe ら ${ }^{(34)}$ は，オオムギ「赤神力」の単一遺伝子突 然変異の半矮性 11 系統の 幼葉䩗について成長速度と IAA の内生量を測定した. 成長が盛んな 播種後 2 日目 に执いては，系統 145 を除き成長速度と IAA の内生量 の間に高い相関があり（図 4), 系統 145 を除く 10 系統 の矮性は IAA 欠損に由来すると考えられた. IAA 欠損

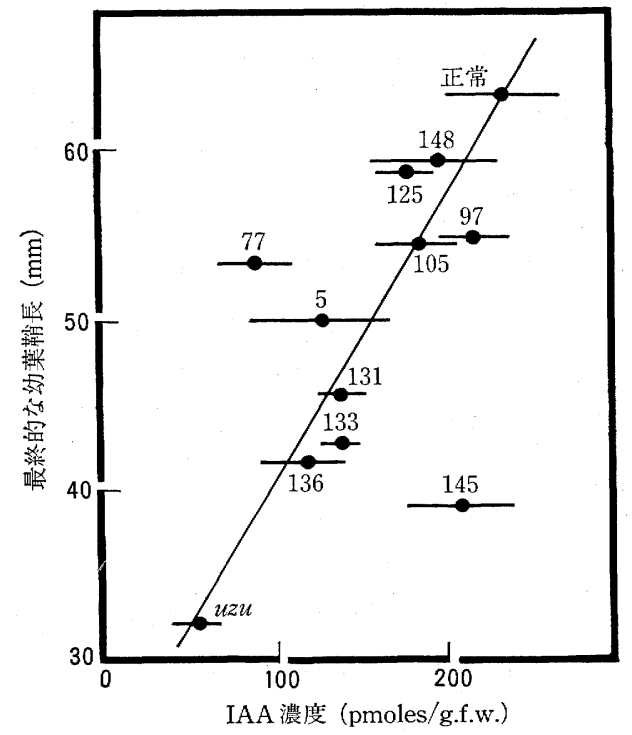

図 4【オオムギの半矮性系統之正常型の播種後 2 日目の 黄化芽生えにおける IAA の内生量と幼葉鞘長との相 関(34)
と矮性の関連については，前回の本セミナー室で詳しく 解説されている. 桜井ら ${ }^{(33)}$ は, IAA 欠損半矮性オオム. ギの中で IAA の内生量が最も低い $u z u$ (渦赤神力) に ついて，その IAA 生合成経路上の久隄段階を追究する 観点から, $10^{-4} \mathrm{M}$ の D-トリプトファンで正常型と $u z u$ 幼葉鞘を処理し，10 時間後の IAA の生成量を測定した ところ, uzu は正常型の約 1/2 であった. したがって, uzuにおいては, D-トリプトファンからインドールピル ビン酸への変換段階を触媒する D-トリプトファンアミ ノトランスフェラーゼに異常があると考えられている.

シロイヌナズナの $\operatorname{trp}-1$ は, トリプトファン生成段階 に異常があり，IAA の内生量が少ない。この変異体は 成長が遅く叢生で葉がちがれ不稔花を生じ，オーキシン 非感受性の $a x r-1$ 亿類似の形態を示す(35).

\section{エチレンと矮性}

エチンンは，細胞の伸長成長の阻害・拡大成長の 促 進, 果実の成熟促進, 屈地性の消失, 頂芽優勢の促進, 離層形成促進など多樣な作用を示すホルモンである. イ ンゲンマメやュムギの矮性品種の中には, 正常型品種よ りもエチレン発生量の多いものが知られている.これら の矮性品種においては，花芽形成，子実体の形成・成熟 などが正常型品種よりもはやい(36). エチレン生成は, オ ーキシンによっても誘導されるほか，傷害・接触など物 理的刺激によっても誘導される. “麦踏み”が人為的に エチレンを発生させてその作用により短桿の丈夫なムギ を育てるためのものであることはよく知られている.

エチレンを過剩に生成する単一遺伝子矮性突然变異 は，筆者の知る限りでは，2例報告されている. 一つ は，エンドウの $l k$ である(37). これは著しく矮化してお 
り，外生的に与光たジベレリンに反応しない，また，上 偏成長がみられ, 頂芽優勢が強く現われ, 正常型のエン ドウをエチレン処理した場合と同様の形態を示す. $l k$ は エチレン生合成阻害剤で処理すると伸長の回復がみら れ，ジベレリンに対しても反応するようになる，乙か し, エチレン生合成阻害剤では限定された回復しかみせ ないことから，lkに和けるエチンンの過㮃生産は, $l k$ 遺 伝子の二次的効果によるものと推定されている.

もら一つはトマトのEpiで, エチレンの前駆体である 1-aminocyclopropane-1-carboxylic acid (ACC) の内生 レベルも高くこれがエチンン過剩生産の原因と考兄ら れている(88). 上偏成長, 茎や葉に掓る肥厚生長なぞが みられ，エチレン過剩を反映した形状を示している. し かし，エチレン生合成阻害剤やエチレン作用阻害剤で処 理しても正常型への回復はみられない( ${ }^{(39)} . E p i$ は, 単純 なエチレン過剩突然変異ではないと考兄られる.

\section{その他の植物ホルモンと矮性}

アブシジン酸 $(\mathrm{ABA})$ の示す, 伸長成長阻害, 種子の 休眠, 気孔の閉鎖による水分調節などの多様な生理作用 のらち，伸長成長阻害に着目すると，ABA を過剩に生 成する植物は矮性を示すことが予期される。しかし現在 のところ，そのような報告例はなく、また $\mathrm{ABA}$ 久損の ため徒長するものもない. ABA 欠損の调萎が顕著な形 態を示すエンドウの $w i l^{(40)}$, トマトの $s i t, f l c, n o t^{(41)}$, シロイスナズナの $a b a^{(42)}$, ジャガイモ (Solanum tuberosum L.) の $d p^{(43)}$, 胎生発芽するトウモロコシの $v p$ $5, w-3, v p-7^{(44)}$ などにおいては，むしろ背丈は正常型 より低いものが多い.

以上のように， $\mathrm{ABA}$ が矮性の 規定要因となってい る突然変異の報告例はないが，カボチャ (Cucurbita maxima Duch.) の黄化芽生えに水ストレスを与えて人 為的に矮性植物を作った場合，背丈と ABA の内生量と の間に高い相関があっだ(45). また，水ストレス処理によ り矮化したカボチャの黄化芽生兄胚軸に括ける細胞壁組 成の変化は，同じ組織に $\mathrm{ABA}$ 処理した場合と同様であ った ${ }^{(46,47)}$. これらの事実は，水ストレス誘導矮性におい ては，ABA が主たる制御要因であることを示唆するむ のとい方よう.

サイトカイニンは, 植物の生活環において, 細胞分裂 促進をはじめとして種々の生理的役割を果たしていると
考兄られるが，成長制御に具体的にどのように関わって いるのかについては，未解明な点が多い，したがって， サイトカイニンの生理作用が顕著に現われるコケや高等 植物のカルスに和いては，サイトカイニン関連の変異体 が報告されているが，無傷植物についてはほとんど報告 例はない. Medford ら ${ }^{(48)}$ は, Agrobacterium のイソペン テニルトランスフェラーゼ遺伝子をタバコ（Nicotiana tabacum L.) とシロイヌナズナに導入し，サイトカイニ ンの内生量が高いトランスジェニック植物を作出した. タバコに扔いては，ゼアチンは約 30 倍, ゼアチンリボ シドは約 50 倍, ゼアチンリボシド-5'-モノリン酸は約 20 倍にも達していた. トランスジェニックタバコの背 丈は，野生型に比べてやや低かったが，側芽数の増加や 根の成長抑制がみられることから，その矮性とサイトカ イニンとを関連づけることは困難である.トランスジェ ニックシロイヌナズナに掠いても根の成長抑制が認めら れたが,タバュ, シロイスナズナともに開花時期は野生 型と変わりがなかった。

最近，第 6 の植物ホルモンとして認められたブラシノ ステロイドについては, 研究の歴史が浅く矮性との関連 において追究された例はない。

以上述べてきたように，現時点で植物ホルモンが関連 すると考兄られる矮性突然变異の大部分は，ジベレリ ン，オーキシン，エチレン関連のもので，乙かもそれら ホルモンの生合成異常によるものであることが明らかに されている.これは，ホルモンの生合成経路の解明が進 み, 微量内生ホルモンの正確な定量が可能になって, ホ ルモンの内生量と植物の表現型との関連付夺が容易にな ったためと考孚られる. 一方，ホルモンの受容体異常や 受容シグナル伝達機構の異常が矮性の要因之考兄られる 矮性突然变異はきわめて少数である.これはホルモン受 容以降の過程が依然としてブラックボックスであるから に他ならない。しかし，上記ホルモンの受容体に関して も最近いくつか注目すべき成果が出ておう，また遺伝子 の機能解析の手法も急速に進歩していることから，今後 矮性の分子レベルでの解析は大きく進展するすのと思わ れる。

矮性との関連が判然としない $\mathrm{ABA}$ ，サイトカイニン, ブラシノステロイドについては，それらホルモンが規定 
要因となっている矮性突然変異が存在するか否かは明ら かでないが，適切なスクリーニング方法の開発，あるい はそれらホルモン生合成遺伝子を導入したトランスジェ ニック植物の作出などにより，矮性との関連が解明され ていくことと思われる.

本稿ををとめるにあたり御助言をいただいた国際基督教大学 の勝見允行教授に感謝します.

\section{文献}

1) P. J. King : Trend in Genetics, 4, 157 (1988).

2) J. B. Reid : in "Plant Gene Research, a Genetic Approach to Plant Biochemistry", ed. by A.D. Blonstein and P. J. King, Spriner-Verlag, Wien, 1986, p. 1.

3) J. B. Reid : J. Plant Growth Regul., 9, 97 (1990).

4) 山根久和, 倉石 晋: “植物生活環の調節”, 高橋信孝編, 東京大学出版会, 1990, p. 356 .

5) N. Takahashi, I. Yamaguchi \& H. Yamane : in "Chemistry of Plant Hormone", ed. by N. Takahashi, CRC Press Inc., Florida, 1986, p. 57.

6) N. Takahashi \& M. Kobayashi : in "Gibberrellins" ed. by N. Takahashi, B. O.Phinney and J.MacMillan, Springer-Verlag, New York, 1990, p. 9.

7) B. O. Phinney \& C. R. Spray: in "Plant Growth Substances 1982", ed. by P.F. Waring, Academic Press, London, 1982, p. 101.

8) J. B. Reid, I. C. Murfet \& W. C. Potts : J.Exp. Bot., 34, 349 (1983).

9) T. J. Ingram, J. B. Reid, I. C. Murfet, P. Gaskin, C. L. Willis \& J. MacMillan : Planta, 160, 455 (1984).

10) T. J. Ingram, J. B. Reid \& J. MacMillan : Planta, 168, 414 (1986).

11) S. Fujioka, H. Yamane, C. R. Spray, B. O. Phinney, P. Gaskin, J. MacMillan \& N. Takahashi : Plant Physiol., 94, 127 (1990).

12) K.S. Albone, P. Gaskin, J.MacMillan, B. O. Phinney \& C. L. Willis : Plant Physiol,, 94, 132 (1990).

13) S. Fujioka, H. Yamane, C. R. Spray, M. Katsumi, B. O. Phinney, P. Gaskin, J. MacMillan \& N. Takahashi : Proc. Natl. Acad. Sci. USA, 85, 9031 (1988).

14) S. B. Rood, D. Pearce \& R.P. Pharis : Plant Physiol., 85, 605 (1987).

15) S. B. Rood, D. Pearce, P. H. Williams \& R.P. Pharis : Plant Physiol., 89, 482 (1989).

16) J. A. Kuhnle, P. H. Moore, W. F. Haddon \& M. M. Fitch : J. Plant Growth Regul., 2, 59 (1983).

17) M. Nakayama, H. Yamane, N. Murofushi, N. Takahashi, L. N. Mander \& H. Seto : J. Plant Growth Regul., in press (1991).

18) S. Fujioka, H. Yamane, C. R. Spray, P. Gaskin, J. MacMillan, B. O. Phinney \& N. Takahashi : Plant Physiol., 88, 1367 (1988).

19) B. O. Phinney : in "Plant Growth Regulation", ed. by R. M. Klein, Iowa State College Press, Ames, Iowa, 1961, p. 489.

20) B. O. Phinney, M. Freeling, D. S. Robertson, C. R. Spray \& J. Silverthorne : in "Plant Growth Substances 1985", ed. by M. Bopp, Springer-Verlag, Berlin, Heidelberg,
1986, p. 55

21) Y. Murakami : in "Plant Growth Substances 1970", ed. by E. J. Carr, Springer-Verlag, Berlin, 1972, p. 166.

22) T. C. Moore, H. Yamane, N. Murofushi \& N. Takahashi: J. Plant Growth Regul., 7, 145 (1988).

23) J. B. Reid \& J. J. Ross : in "Gibberrellins", ed. by N. Takahashi, B. O. Phinney and J. MacMillan, SpringerVerlag, New York, 1990, p. 40.

24) M. Talon, M. Koornneef \& J. A. D. Zeevaart : Proc. Natl. Acad. Sci. USA, 87, 7983 (1990).

25) J. A. D. Zeevaart : Plant Physiol. Supp1., 75, 186 (1984).

26) N.P. Harberd \& M. Freedling: Genetics, 121, 827 (1989).

27) M. Radley: Planta, 92, 292 (1970).

28) J. R. Lenton, P. Hedden \& M. P. Gale : in "Hormone in Plant Development", ed. by G. V. Hoad, J. R. Lenton, M. B. Jackson and R. K. Atkin, Butterworth, London, 1987, p. 145.

29) M. Talon, M. Koornneef \& J.A. D.Zeevaart : Planta, 182, 501 (1990).

30) K. Endo, H. Yamane, M. Nakayama, I. Yamaguchi; N. Murofushi, N. Takahashi \& M. Katsumi : Plant Cell Physiol., 30, 137 (1989).

31) D. M. Law : Physiol. Plant., 70, 626 (1987).

32）小柴共一：植物化学調節学会平成元年度大会研究発表記録 集, 1989 , p. 30 .

33）桜井直樹：文部省特定研究「植物の生活環調節機構の動的 解析」C系公開シンポジウム「植物の生長・物質蓄積の制 御」講演要旨集, 1989, p. 5.

34) M. Inouhe, N. Sakurai \& S. Kuraishi : Plant Cell Physiol., 23, 689 (1982).

35) R. L. Last \& G. R. Fink: Science, 240, 305 (1988).

36) Y.Aharoni, C. T. Phan \& M.Spencer : Can. J. Bot., 51, 2243 (1973).

37) J. J. Ross \& J. B. Reid : Physiol. Plant., 75, 81 (1986).

38) D. W. Fujino, D. W. Burger, S. F. Yang \& K. J. Bradford : Plant Physiol., 88, 774 (1988).

39) D. W. Fujino, D. W. Burger \& K. J. Bradford : J. Plant Growth Regul., 8, 53 (1989).

40) T. L. Wang, M. E. Donkin \& E. S. Martin : J.Exp. Bot., 351, $1222(1984)$

41) M. Koornneef, M. L. Jorna, D. L. C. Brinkhorst-van der Swan \& C. M. Karssen : Theor. Appl. Genet., 61, 385 (1982).

42) S. J. Neil \& R. J. Horgan : J. Exp. Bot., 36, 1221 (1985).

43) S. A. Quarrie : Plant Cell Envir., 5, 23 (1982).

44) R. Moore \& J. D. Smith : Planta, 164, 126 (1985).

45) N. Sakurai, M. Akiyama \& S. Kuraishi : Plant Cell Physiol., 26, 15 (1985).

46) N. Sakurai, S. Tanaka \& S. Kuraishi : Plant Cell Phys iol., 26, 15 (1987).

47) K. Wakabayashi, N. Sakurai \& S. Kuraishi : Physiol. Plant., 75, 151 (1989).

48) J. I. Medford, R. Horgan, Z. El-Sawi \& H. J. Klee : Plant Cell, 1, 403 (1989). 